\title{
Effect of self-hypnosis on the experience of delivery fear and duration of labor in primiparity: A randomized clinical trial
}

\author{
Batool Kamalimanesh ${ }^{\left(D^{1}\right.}$, Maryam Moradi ${ }^{2,3}{ }^{2,3}$ Mehdi Fathi $^{(1)}{ }^{4}$, Maliheh Afiat ${ }^{5}$, Mahnaz \\ Boroumand Rezazadeh ${ }^{5}$, Mohammad Taghi Shakeri ${ }^{6}$
}

\begin{abstract}
Background and Aims: Fear of delivery in females can lead to negative side effects, such as the experience of long and hard labor. Reduction of delivery fear is one of the goals of natural delivery program, and hypnosis has been considered a way to reduce this fear. With regard to the contradictory results of the studies in this field, this study aimed to determine the effect of self-hypnosis on the experience of delivery fear and duration of labor in primiparity.
\end{abstract}

Materials and Methods: This clinical trial was conducted on 63 pregnant women who were divided into self-hypnosis $(n=30)$ and control groups $(n=33)$ using a blocking method in Mashhad, Iran, during 2019. The intervention group received two sessions of hypnosis at $37^{\text {th }}$ and $38^{\text {th }}$ weeks of pregnancy which consisted of listening to an audio file until delivery time. On the other hand, the control group received only the routine care. Fear was evaluated at $37^{\text {th }}$ week of pregnancy and $24 \mathrm{~h}$ after delivery. Data were analyzed using SPSS software (version 16), and a p-value less than 0.05 was considered statistically significant.

Results: The mean scores of delivery fear experience $(\mathrm{P}<0.001)$, as well as the duration of the second stage $(\mathrm{P}=0.013)$ and third stage of labor $(\mathrm{P}=0.009)$ were significantly lower in the self-hypnosis group, compared to the controls.

Conclusion: Self-hypnosis was effective in reducing the experience of delivery fear and duration of the second and third stages of labor in primiparity. Therefore, self-hypnosis is recommended to reduce the experience of delivery fear and duration of the second and third stages of labor in primiparity.

Keywords: Delivery fear, Hypnosis, Labor, Primiparity, Self-hypnosis

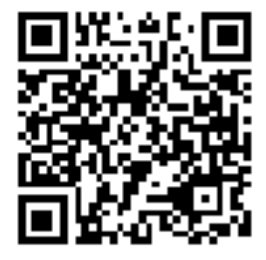

Citation: Kamalimanesh B, Moradi M, Fathi M, Afiat M, Boroumand Rezazadeh M, Shakeri MT. [The effect of self-hypnosis on the experience of fear of delivery and duration of labor in primiparity women: randomized clinical trial]. J Birjand Univ Med Sci. 2021; 28(1): 11-23. [Persian]

DOI http://doi.org/10.32592/JBirjandUnivMedSci.2021.28.1.101

Received: July 30, 2020

Accepted: November 17, 2020

\footnotetext{
${ }^{1}$ Student Research Committee, School of Nursing and Midwifery, Mashhad University of Medical Sciences, Mashhad, Iran 2 Nursing and Midwifery Care Research Centre, Mashhad University of Medical Sciences, Mashhad, Iran

3 Department of Midwifery, School of Nursing and Midwifery, Mashhad University of Medical Sciences, Mashhad, Iran

4 Department of Anesthesia, School of Medicine, Mashhad University of Medical Sciences, Mashhad, Iran

5 Department of Obstetrics and Gynecology, School of Medicine, Mashhad University of Medical Sciences, Mashhad, Iran

${ }^{6}$ Department of Biostatistics, School of health, Mashhad University of Medical Sciences, Mashhad, Iran
}

Corresponding author: Nursing and Midwifery care Research Centre, Mashhad University of Medical Sciences, Mashhad, Iran Tel: $+985138591511-3$ 


\section{تاثير خود-هيينوتيزم بر تجربه ترس از زايمان و طول مدت ليبر در زنان نخست زا: كار آزمايى بالينى تصادفى شده}

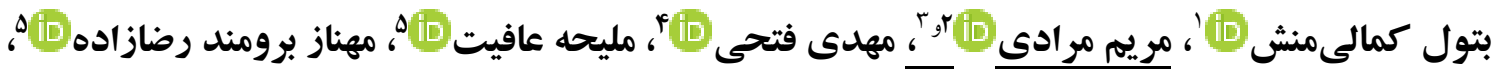 محمدتقى شاكرى (iD}

\section{جككيله}

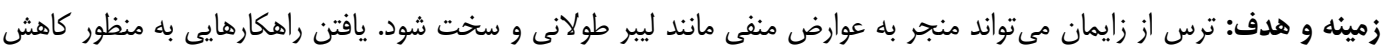

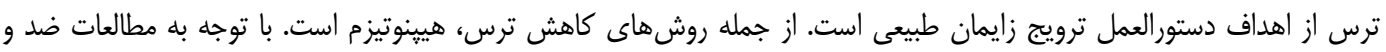

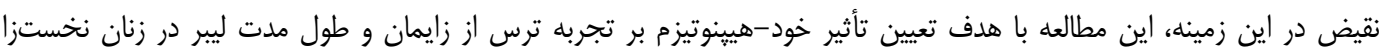
انجام شد.

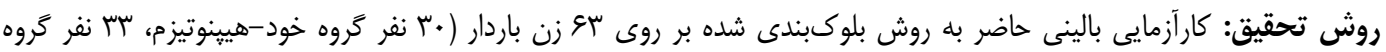

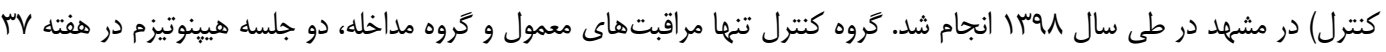

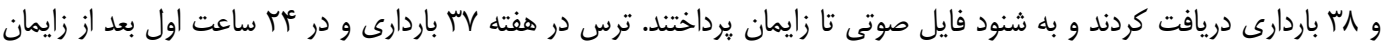

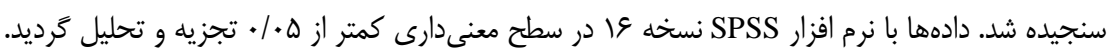

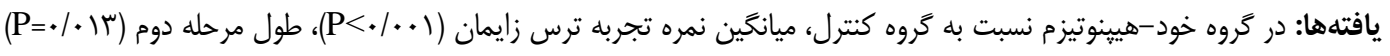

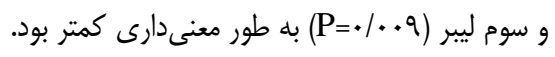

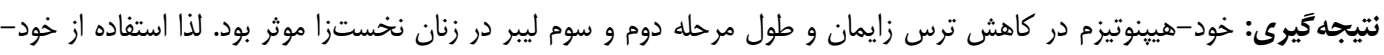

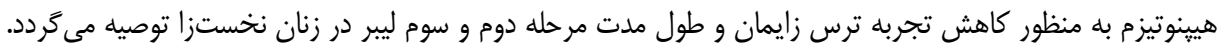

$$
\begin{aligned}
& \text { وازههاى كليدى: ترس از زايمان، هيينوتيزم، ليبر، نخستزا، خود-هيينوتيزم }
\end{aligned}
$$

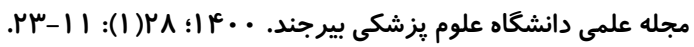

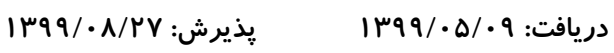

'عضو كميته تحقيقات دانشجويى، دانشكده يرستارى مامايى، دانشكاه علوم يزشكى مشهل، مشهرد، ايران

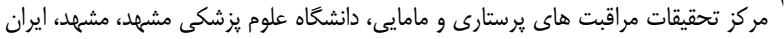

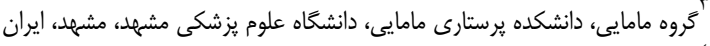

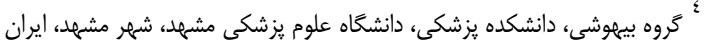

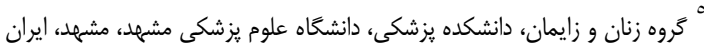

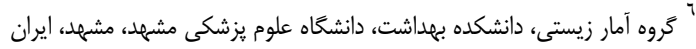

نويسنده مسئول: مركز تحقيقات مراقبت هاى يرستارى و مامايى، دانشخاه علوم يزشكى مشهرد، مشهلد، ايران

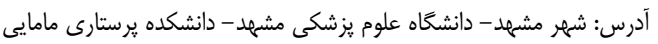

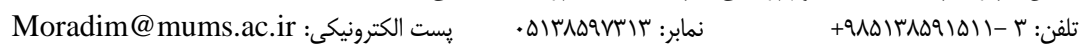


افزايش و آكاهى محيطى كاهش مىيابد و به صورت افزايش در

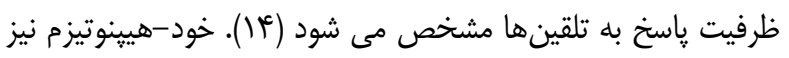

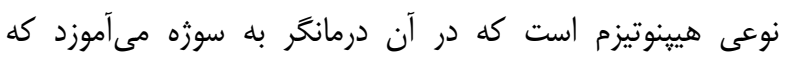

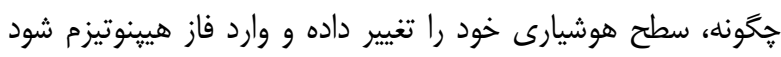

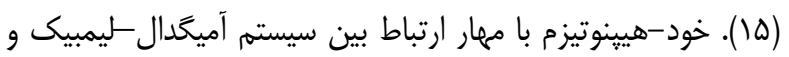
كورتكس مغز، از تفسير احساساتى كه در حال تجربه هستند

$$
\text { جلو }
$$

از آنجا كه طبق بررسى هاى انجام (لام شده، كارآزمايى بالينى در زمينه تأثير هيينوتيزم يا خود-هيينوتيزم بر ترس و طول مدات لهات زايمان در ايران يافت نشد و مطالعات انجام شده در ساير جوامع داراى نتايج ضد و نقيض مىباشند، لذا با توجه به شيوع و اهميت ترس از زايمان

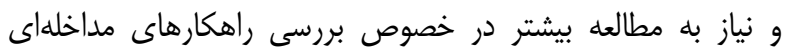

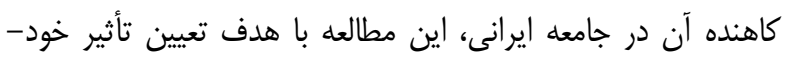
هيينوتيزم بر تجربه ترس از زايمان و طول مدت زايمان انجام شد.

\section{روش تحقيق}

مطالعه حاضر در قالب كارآزمايى بالينى تصادفى به روش موازى

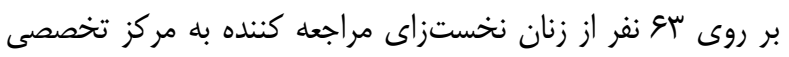

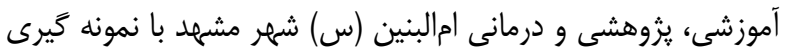

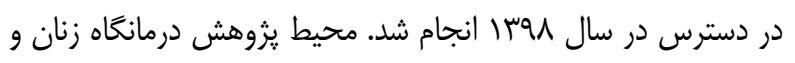

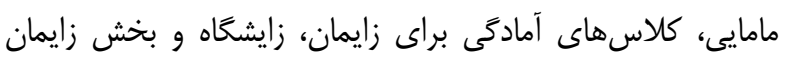

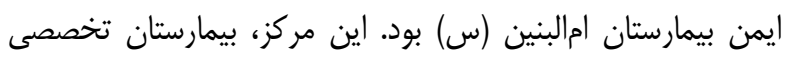

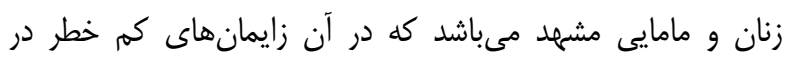
اتاقهاى 'LDR انجام مىشود. علاوه بر آمار بالاى زائ زايمان،

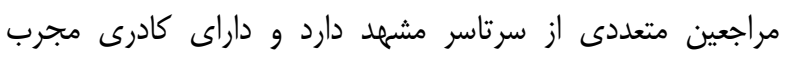

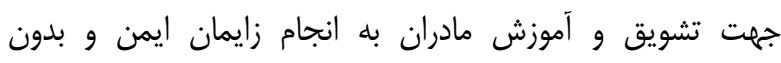

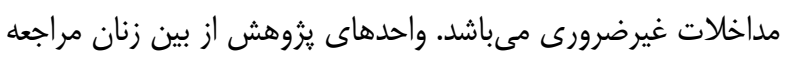

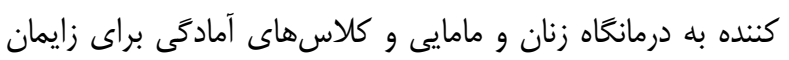

$$
\text { بيمارستان امالبنين (س) انتخاب شدند. }
$$

حجم نمونه با استفاده از فرمول مقايسه ميانكينها در دو كروهاب مستقل مداخله و كنترل با ضريب آلفا $1+٪$

${ }^{1}$ Labor Delivery Room

\section{مقال}

انتقال فيزيولوزيك از مرحله باردارى به مرحله مادرى، مىتواند

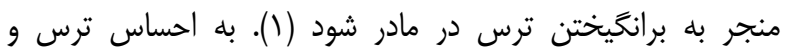

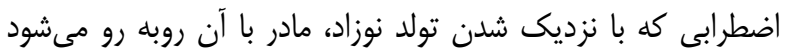

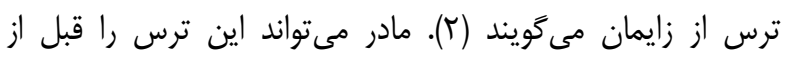

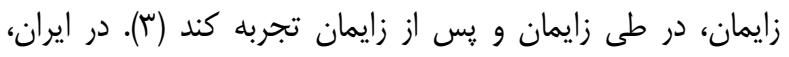

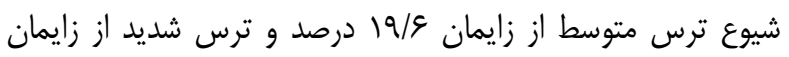

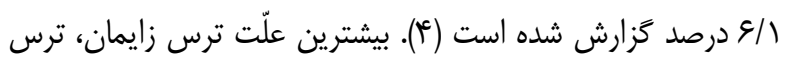
از درد زايمان و سلامت نوزاد مىباشد (ه). بهطورى كه بيشتر زنان داراى ترس زايمان، سزارين انتخابى را ترجيح مىدهند (و). از ديخر

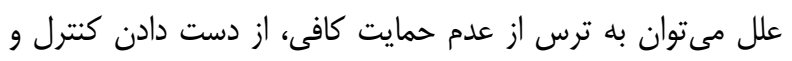

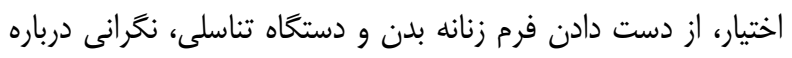
مشكلات جنسى، كاهش رضايت جنسى همسر بعد از زايمان و عدم

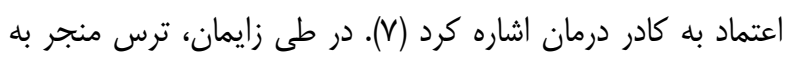

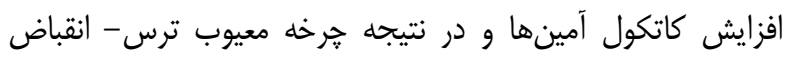

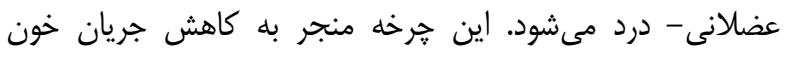

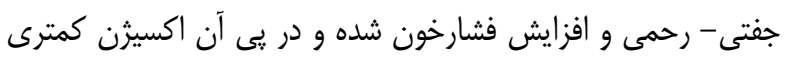

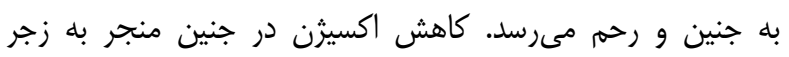
جنين و در رحم منجر به كاهش انقباضات رحمى، كاهش ترشح

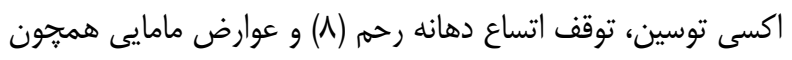

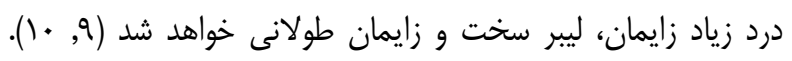
تاكنون مداخلات متعدّدى جهت كاهش ترس از زايمان انجام شده

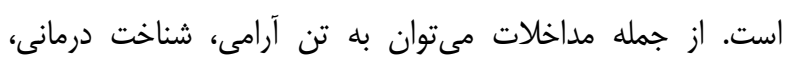

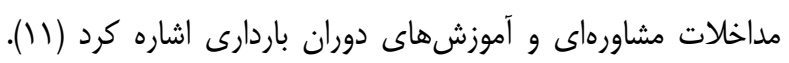
هرجند زنان باردار تحت مشاوره در كل از حمايت انجام شده رضايت

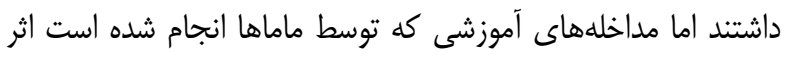
جزئى در كاهش ترس، بهبود تجربه زايمان و كاهش ميزان سزارين

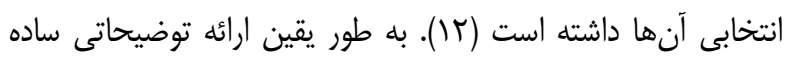
براى كاهش اضطراب ناشى از احساس ناتوانى شديد براى زايمان كافى نخواهد بود (س) (1). از ديخر روشهايى كه مىتوان با آن ترس را كاهش داد هيينوتيزم است. هيينوتيزم حالتى از هوشيارى است كه در آن تمركز 
روشهاى بىدردى بى حسى نخاعى و انتونوكس در زايمان، دريافت

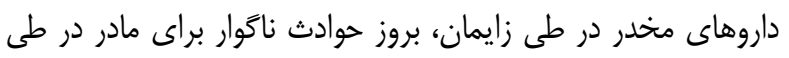

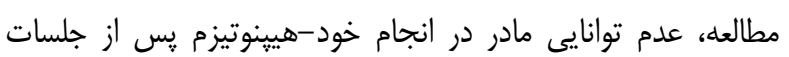
آموزشى و عدم توانايى مادر در انجام خود-هيينوتيزم در طى ليبر بود.

\section{ابزارها}

در اين يزوهش از ينج ابزار فرم پزوهشخر ساخته اطلاعات

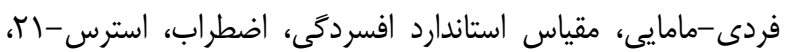

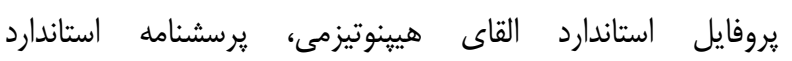

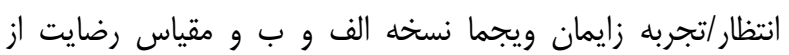
زايمان مك كى استفاده شد.

\section{يروفايل القاى هيينوتيزمى}

در اين روش به آزمودنى كَفته مىشود: "سرتان را در حالتى

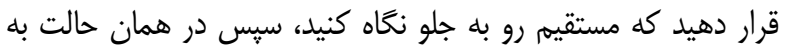
بالا و به سمت ابروهايتان نغاه كنيد، سيس نغاه خود را به نوى سرتان بدوزيد (نخاه فوقانى). سيس در حالى كه به سمت بالا نغاه

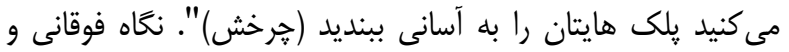
קرخش بر حسب مشاهده ميزان صلبيه قابل رؤيت در حد فاصل

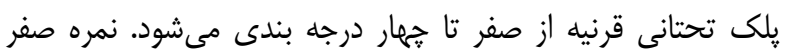
بيانكر عدم هيينوتيزم يذيرى است. نمره ا نشاندهنده هيينوتيزم

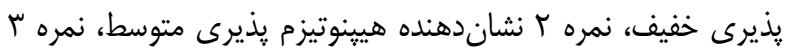

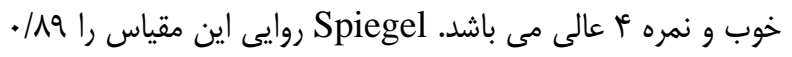

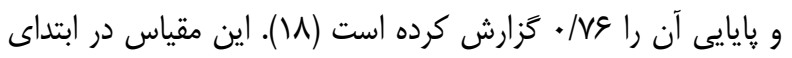
هفته VIV باردارى توسط يزوهشكر تكميل شد.

\section{مقياس افسردكى، اضطراب، استرس - (1)}

اين مقياس شامل اب سؤال با مقياس ليكرت است كه V سؤال

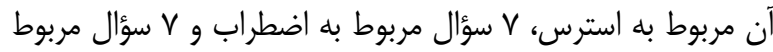

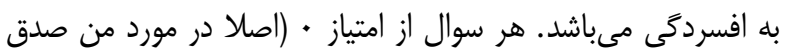

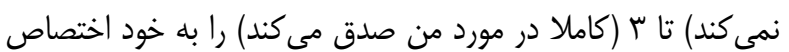

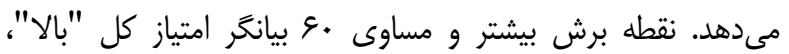

هدف مقايسه ترس از زايمان بر روى ده نفر اول به روش پايلوت

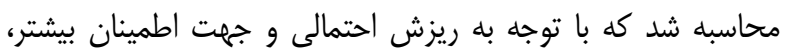
تعداد •r نمونه در هر كَروه تعيين كَرديد

$$
\text { . }\left(Z_{1-\alpha / 2}=r / \Delta \wedge ، Z_{1-\beta}=1 / \Gamma\right)
$$

$$
n_{1}=n_{2}=\frac{\left(S_{1}{ }^{2}+S_{2}{ }^{2}\right)\left(Z_{1-\frac{\alpha}{2}}+Z_{1-\beta}\right)^{2}}{\left(\bar{X}_{1}-\bar{X}_{2}\right)^{2}}
$$

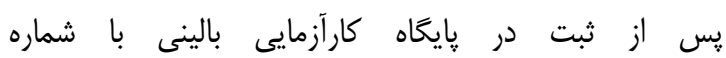
IRCT20190129042538N1 تردآورى دادهها IR.MUMS.NURSE.REC.1398.005 آغاز گرديد. معيارهاى ورود به مطالعه شامل داشتن رضايت آكاهانه،

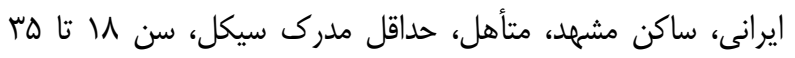

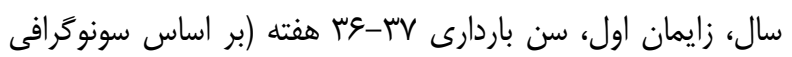

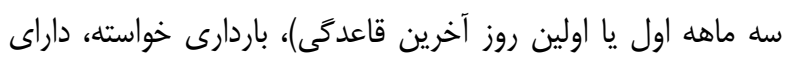

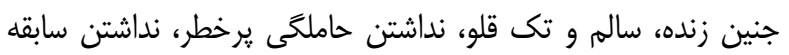

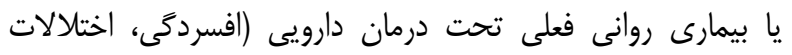

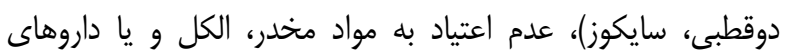
روان كردان، فاقد انديكاسيون اوليه سزارين، قصد انجام زايمان طبيعى در بيمارستان محل يزوهش، عدم بروز حوادث ناتوار براى مادر در شش ماه كذشته، كسب نمره كمتر از •و براى امتياز كل و

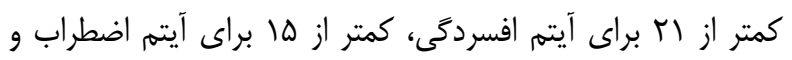

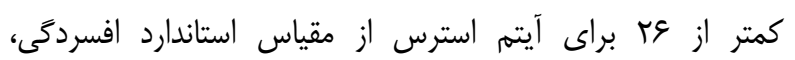

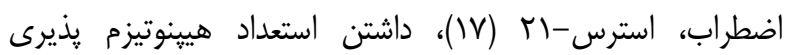

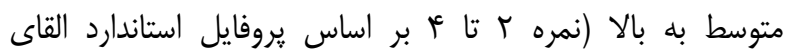

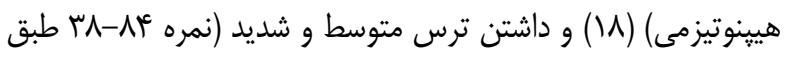

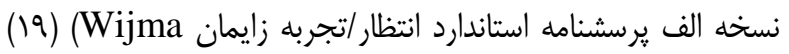

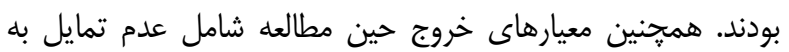

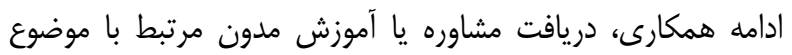

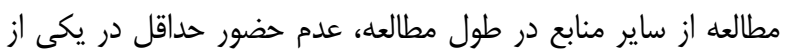

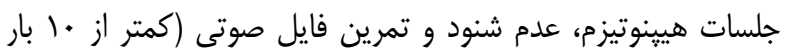
تمرين)، تغيير بيمارستان محل زايمان، زايمان سزارين، استفاده از 


\section{مقياس رضايت از زايمان مك كى}

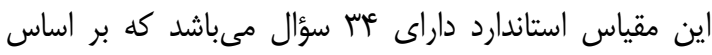

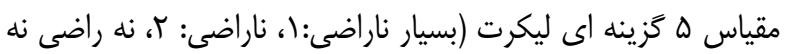

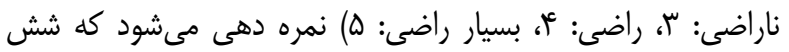

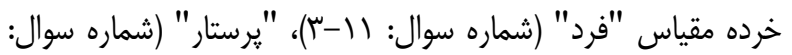

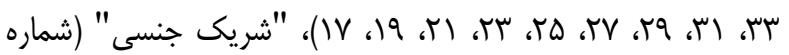

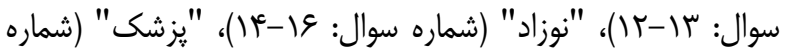

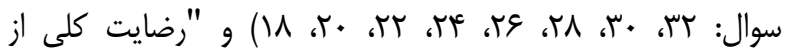

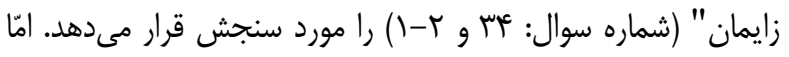

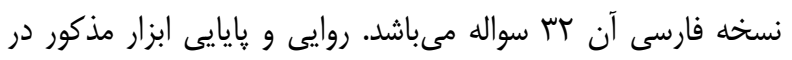

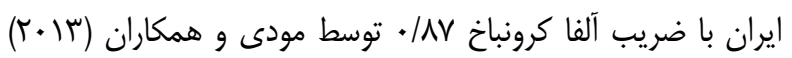

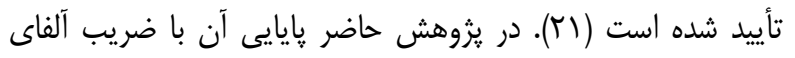

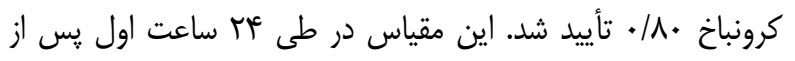
زايمان تكميل شد.

واحدهاى يزوهش به روش بلوك بندى شده عا تايى و بر اساس

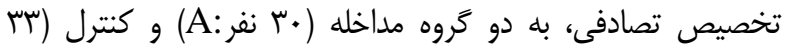
نفر:B) تقسيه شدند. بدين صورت كه يزوهشگر كليه بلوكهاى

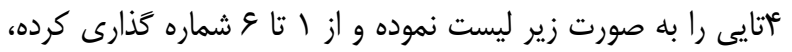
سبس همه اعداد ا تا ع را به صورت تصادفى با استفاده از نرم افزار اكسل توليد و به ترتيب بلوكهاى منتسب به آنها را يادداشت نموده

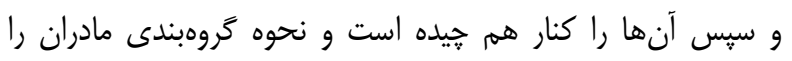
مشخّص نموده است.

(AABB, ABBA, ABAB, BBAA, BAAB, BABA)

كروه كنترل تنها مراقبتهاى روتين باردارى و زايمان ران دريافت كردند. كليه مراقبت هاى مامايى و زايمان در طول مدّت بسترى توسط ماماها و رزيدنتها در هر دو گروه صورت كرفت. كروه مداخله علاوه بر مراقبتهاى روتين، دو جلسه هيينوتيزم (•9-4

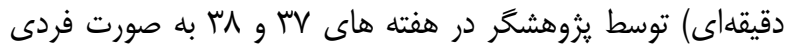
دريافت كردند. جلسه اول به ارائه توضيحاتى در مورد كليات

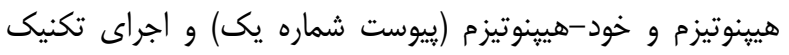

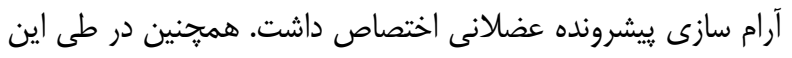
جلسه تلقينهايى با هدف تصويرسازى خوشايند نسبت به اتاق
بيشتر و مساوى الr بيانكر افسردگى "شديد"، بيشتر و مساوى 10

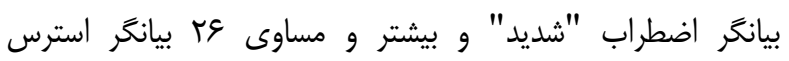

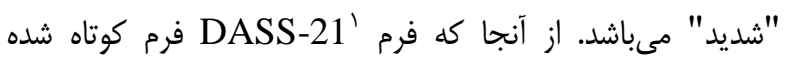
مقياس اصلى است (Tr سوالى)، بايستى نمره نهايى هر خرده مقياس را دو برابر محاسبه كرد (IV). روايى اين مقياس از طريق تحليل

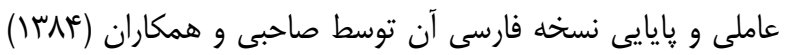

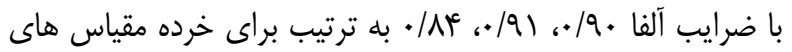

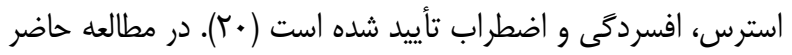

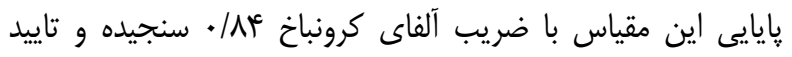
شد. اين مقياس در ابتداى هفته لَّ باردارى تكميل شد.

\section{يرسشنامه انتظار /تجربه زايمان ويجما نسخه الف و ب}

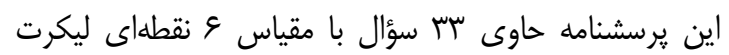
بوده، بدين صورت كه صفر به مفهوم "كاملاً" و پينج به معنى "اصلاً

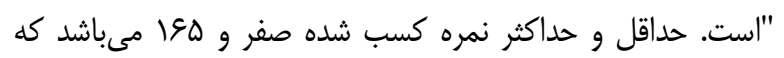

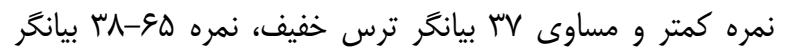

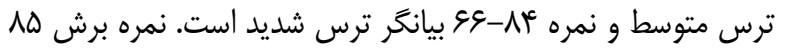

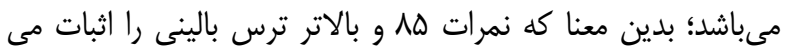

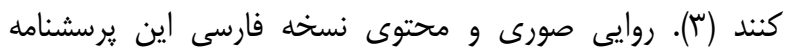

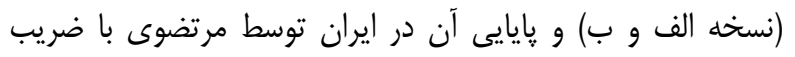

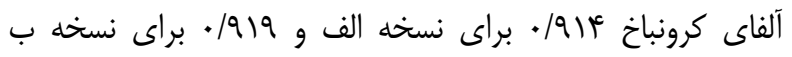

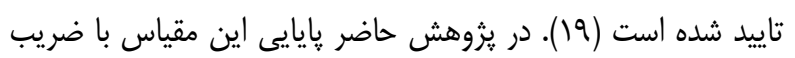

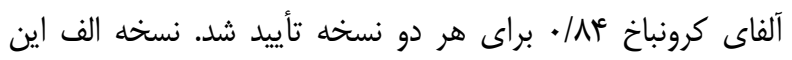
يرسشنامه جهت سنجش انتظار از زايمان طراحى شده كه در دوران

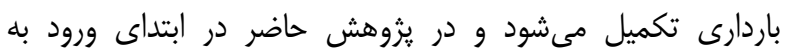
مطالعه در هفته VV باردارى (قبل از آموزش خود-هيينوتيزم) تكميل شد. همجنين نسخه ب اين يرسشنامه جهت سنجش تجربه زايمان

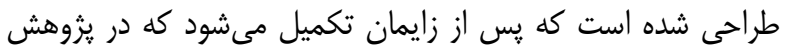
حاضر نيز در طى ثب ساعت اول يس از زايمان تكميل شد.

\footnotetext{
${ }^{1}$ Depression Anxiety Stress Scale- 21
} 
جلسات آموخته است از زمان يذيرش در بيمارستان تا بايان زايمان

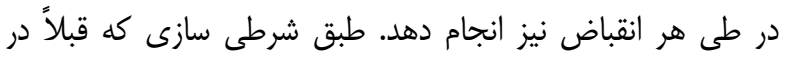

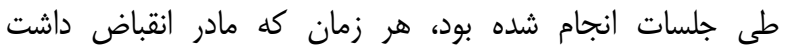
ناخودآكاه انگشت شست راست خود را در داخل مشت همان دست قرار داده و فشار مى داد و جند مرتبه نفس عميق مى كشيد و وارد فاز شل شدگى عضلانى مى شد. بدين صورت مادر در عرض جند ثانيه وارد فاز هيينوتيزم مىشد و از انقباضات منفى مى كَرديد. در اين فاز

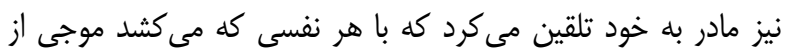

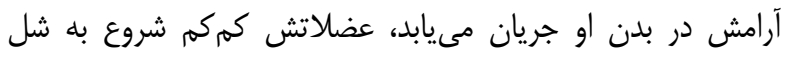
شدن مى كنند و حالت خميرى به خود مى گيرند و جنين در اين بافت خميرى راحت به بيرون سر مى خورد.

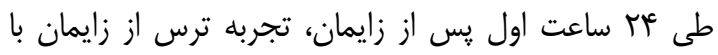

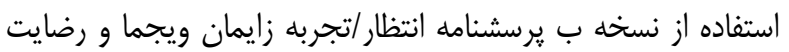

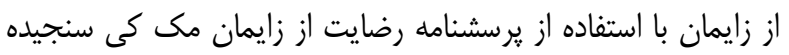

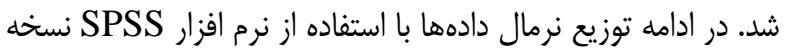

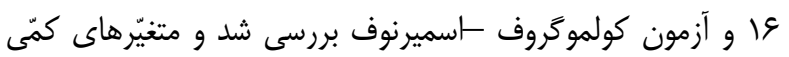
نرمال با استفاده از آزمون تى مستقل، كمّى غيرنرمال با استفاده از

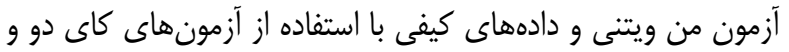
دقيق فيشر در سطح معنىدارى كمتر از هـ/. تجزيه و و تحليل

\section{يافته ها}

بو نفر مادر واجد شرايط وارد مطالعه شدند و در نهايت •ب نفر در گروه خود-هيينوتيزم و سץ نفر در گروه كنترل مطالعه را تكميل كردند. دلايل ريزش در شكل شماره ا ذكر شده است. اطلاعات دموكرافيك و مامايى شركت كنندًان در جدول ا نشان داده شده است. نتايج نشان داد كه دو كروه از نظر متغيّرهاى دموكرافيك و مامايى قبل از مداخله همخن بودند. ميانخين و انحراف معيار تجربه

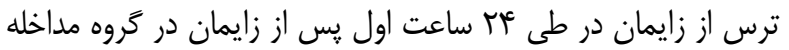


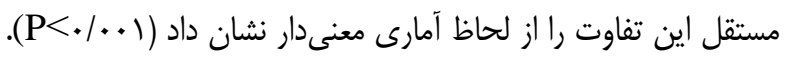

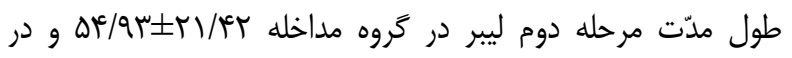

زايمان و شرطى سازى نسبت به انقباضات و انفكاك از درد ايجاد

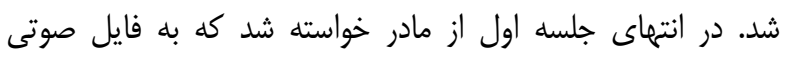

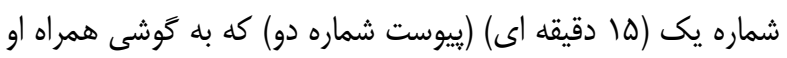

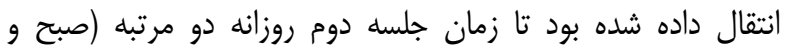
عصر) به وسيله هندزفرى در منزل گوش فرا دهد. در جلسه دوم موارد ذكر شده در جلسه اول مجددا تمرين و تكرار شدند. ضمن اينكه شرطى سازى نسبت به دست ماما به جهت كاهش ترس و درد

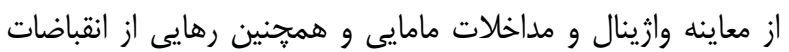

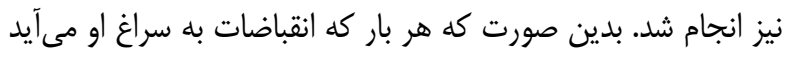

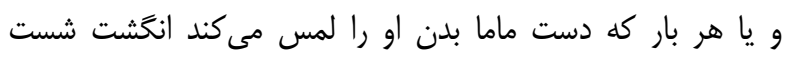

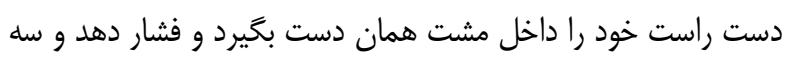

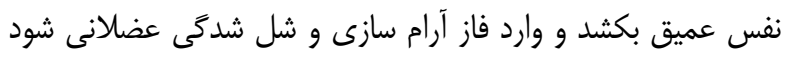
و از انقباضات منفك شود. همجنين تصويرسازى زايمان براى كاهش ونش

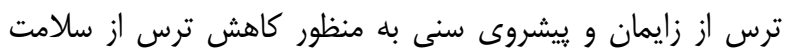

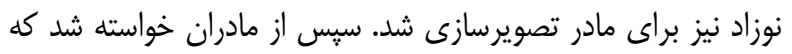

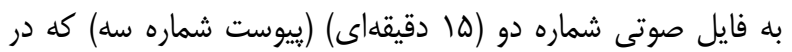

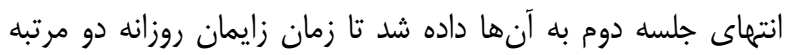
(صبح و عصر) گوش فرا دهد و به تمرين خود-هيينوتيزم در منزل بيردازد. فايل صوتى شماره دو، نسخه كاملتر فايل صوتى شماره

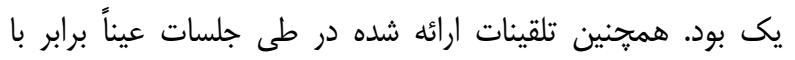
محتواى فايلهاى صوتى بود. فايل صوتى با محتواى كنترل ترس زايمان زير نظر اساتيد مشاوره تخصصى و راهنما، از طريق مصاحبه با V نفر از زنان واجد شرايط مطالعه در مورد نخرش و و احساسات نسبت به زايمان و دلايل ترس از زايمان با صداى يثوهشكر تهيه

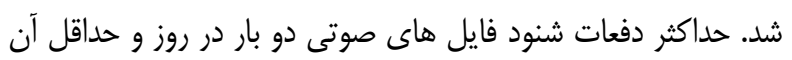
ده بار در هفته بود. همجنين از مادران نيز خواسته شده بود كه به دهاب محض بسترى در زايشكاه با يزوهشخر تماس بخيرند تا يزوهشكر بر

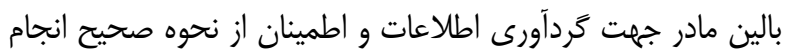
خود-هيينوتيزم توسط مادر و مديريت عارضه احتمالى ناشى از خود-

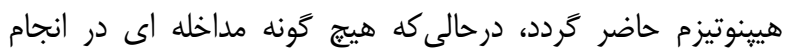

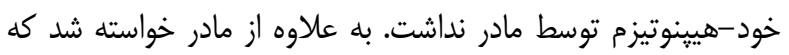

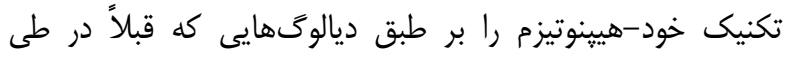


تفاوت معنى دارى مشاهده نشد. تنها اختلاف از نظر مصرف هيوسين و دريافت مايعات وريدى در طى مرحله اول ليبر

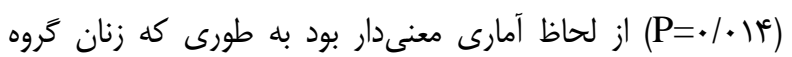

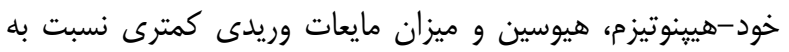

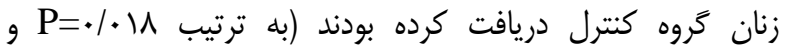

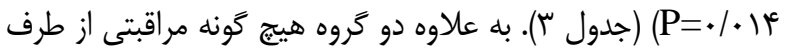
ماماى همراه دريافت نكردند و عارضه جانبى خاصى نيز توسط شركت كنندًان كزارش نشد.
كروه كنترل r./

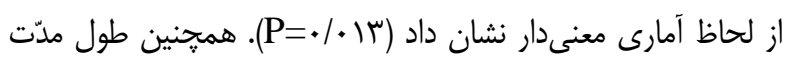

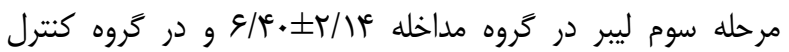

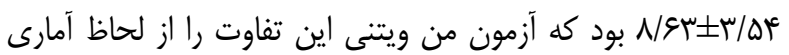

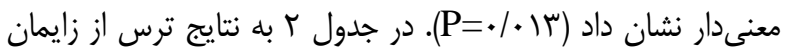
و طول مدت ليبر اشاره شده است. از نظر متغيّرهاى تقويت ليبر،

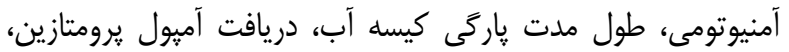

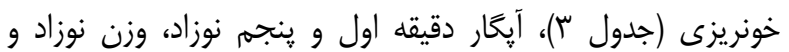

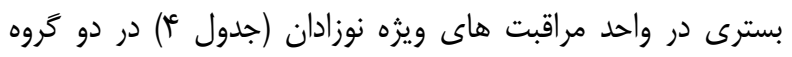

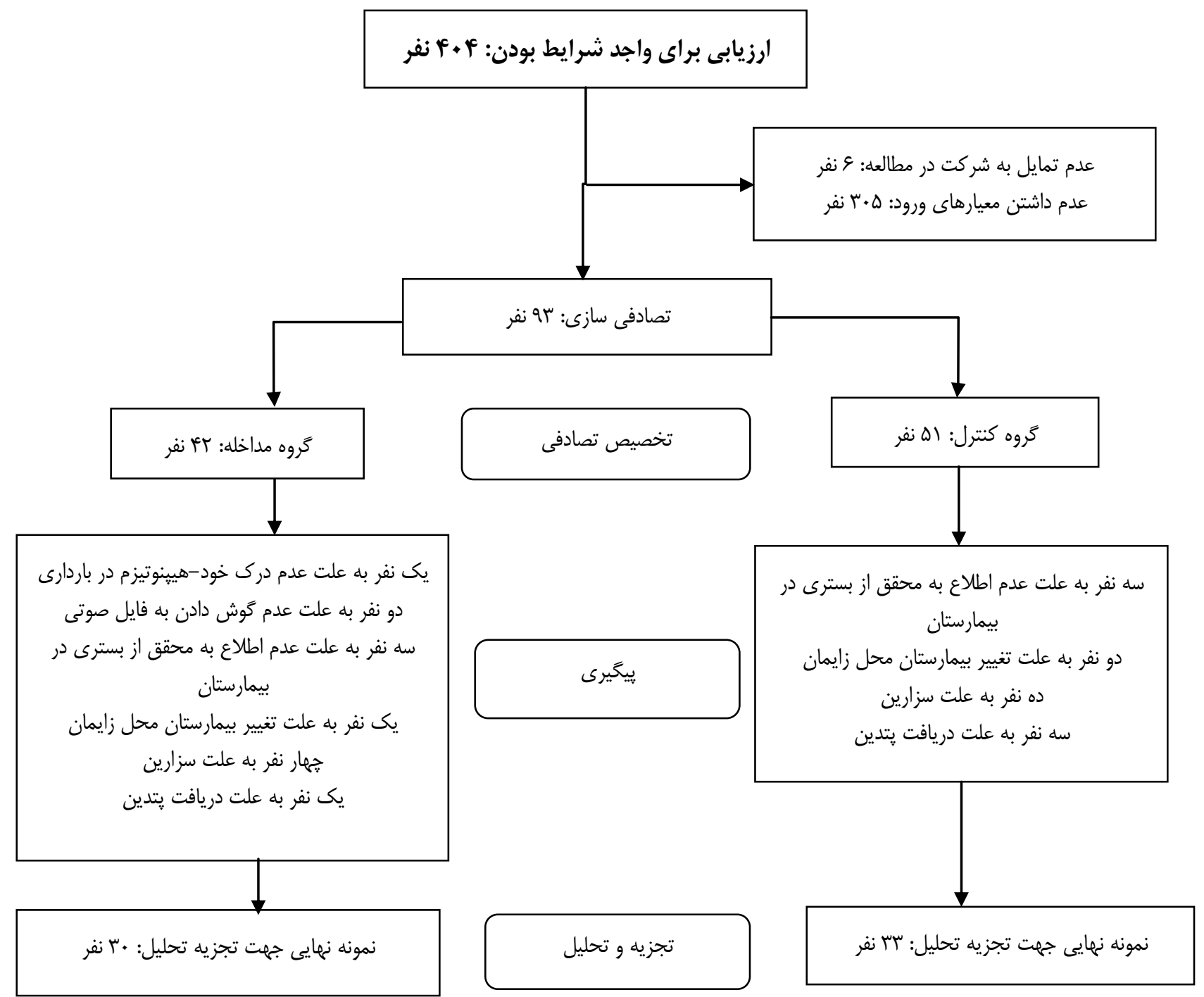

شكل ا - فلوجارت نحوه نمونه كيرى از جامعه يزوهش 
جدول ا - اطلاعات دموكَرافيك و مامايى در دو تروه مداخله و كنترل

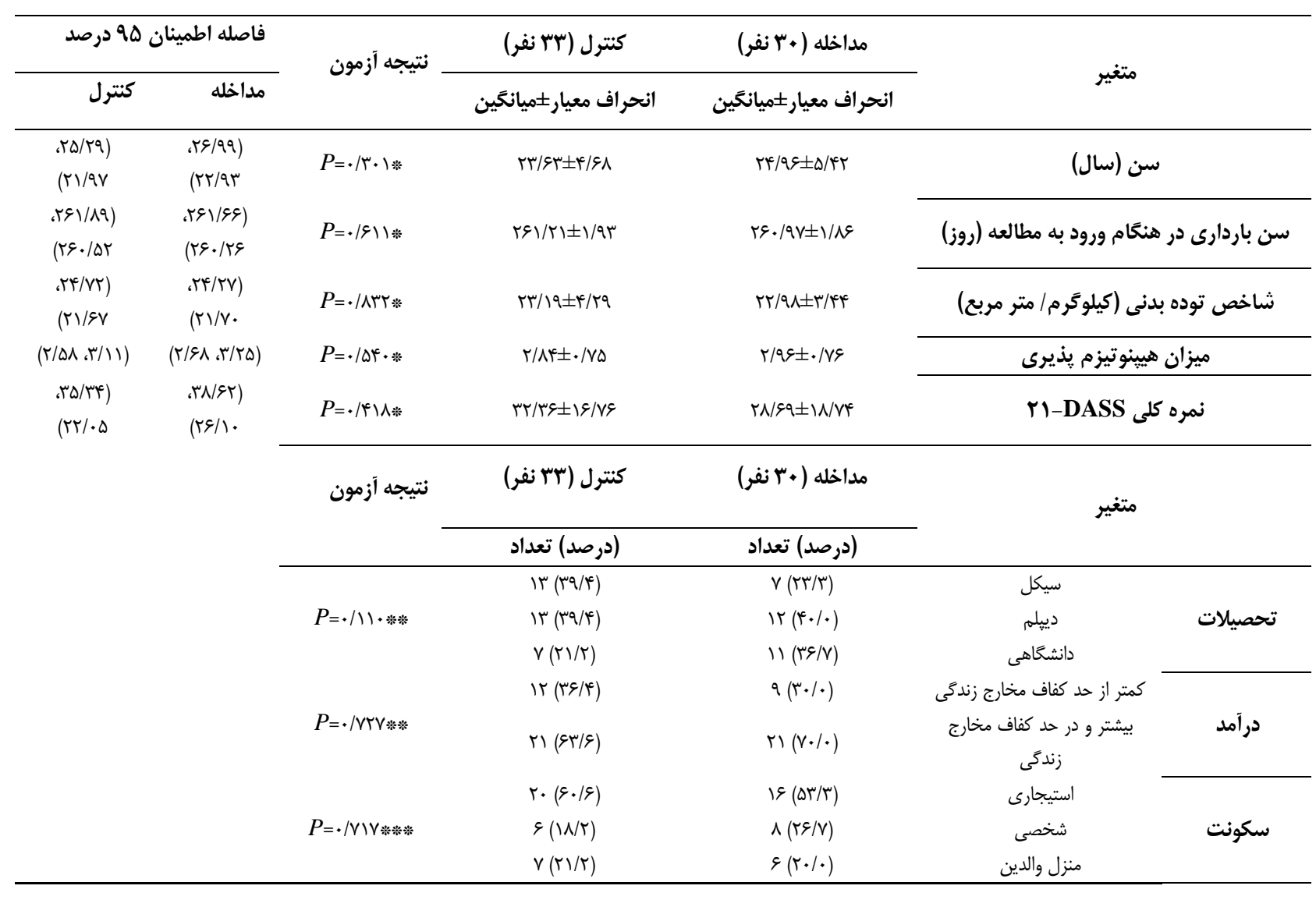

*تى مستقل، *** من ويتنى، **** كاى اسكوئر

جدول r- مقايسه ترس از زايمان و طول مدت ليبر در دو تروه مداخله و كنترل

\begin{tabular}{|c|c|c|c|c|c|}
\hline \multicolumn{2}{|c|}{ فاصله اطمينان ه9 درصد } & \multicolumn{4}{|c|}{ تَروه } \\
\hline & & \multirow{2}{*}{ نتيجه آزمون بين كَروهى } & \multirow{2}{*}{ انحراف معيار \ـميانكَين (سب نفر) } & \multirow{2}{*}{ 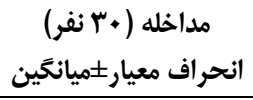 } & \multirow{2}{*}{ طول مدت ليبر (دقيقه) } \\
\hline 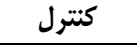 & مداخله & & & & \\
\hline$g 9 / 4 \wedge)$ & $.89 / 1 \%)$ & \multirow{2}{*}{$P=\cdot /$ १マ** } & \multirow{2}{*}{$q H / \Delta r \pm I g / V^{c}$} & \multirow{2}{*}{ s $/ \cdot \cdot \pm 18 / 4 \mu$} & ترس از زايمان در هفته rV \\
\hline$(\Delta \vee / \varepsilon$. & $(\Delta \& / \wedge \mathcal{A}$ & & & & باردارى \\
\hline (૧人/৭४) & $\left.\sqrt{x} \varepsilon / V^{\mu}\right)$ & \multirow{2}{*}{$P<\cdot / . .1 *$} & \multirow{2}{*}{$91 / \cdot . \pm r r / \Delta r$} & \multirow{2}{*}{$\lceil\mid / 99 \pm 1 \% / \Delta V$} & تجربه ترس از زايمان در ب؟ \\
\hline$(\lambda \mu / \cdot)$ & ( ) & & & & ساعت اول يس از زايمان \\
\hline 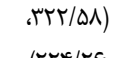 & (ז\&D/ & \multirow{2}{*}{$P=\cdot / 1 \cdot 9 *$} & \multirow[t]{2}{*}{ TVT/KTIIKN/GT } & \multirow[t]{2}{*}{$r \mid N / \wedge r \pm I r Y / M r$} & \multirow{2}{*}{ مرحله اول ليبر (دقيقه) } \\
\hline (TMY/TE & $(I V Y / F \wedge$ & & & & \\
\hline$(\Lambda \uparrow / \uparrow 9)$ & $\mathscr{G} / 9 \Psi)$ & \multirow{2}{*}{$P=\cdot / \cdot 1 \mu^{*}$} & \multirow{2}{*}{$V / / \Lambda) \pm r \cdot / \cdot r$} & \multirow{2}{*}{$\Delta F / Q T \pm T / / F r$} & \multirow{2}{*}{ مرحله دوم ليبر (دقيقه) } \\
\hline$(8) / I V$ & (\$\&/9) & & & & \\
\hline$(\mathrm{V} / \mathrm{\sim} \wedge ، \mathrm{q} / \wedge q)$ & $(\Delta / \Delta Q ، V / T \cdot)$ & $P=\cdot / . \cdot 9 * *$ & $N / G H \pm r / \Delta F$ & $\varepsilon / r \cdot \pm r / / F^{c}$ & مرحله سوم ليبر (دقيقه) \\
\hline$(F) / F Y)$ & 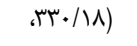 & \multirow{2}{*}{$P=\cdot|\cdot \Delta| *$} & \multirow{2}{*}{$r \Delta F / \cdot r \pm 1 \Delta q / \cdot \Delta$} & \multirow{2}{*}{$r V Q / \Lambda \cdot \pm I r r / q r$} & \multirow{2}{*}{ طول مدت كل ليبر (دقيقه) } \\
\hline (rav/qu & $(r+q / F)$ & & & & \\
\hline
\end{tabular}


جدول بـ- مقايسه بيامدهاى مادرى در دو تروه مداخله و كنترل

\begin{tabular}{|c|c|c|c|c|c|}
\hline \multicolumn{2}{|c|}{ فاصله اطمينان Q9 } & \multirow[t]{2}{*}{ نتيجه آزمون } & كنترل & 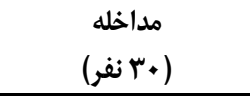 & \multirow[t]{2}{*}{ متغير } \\
\hline 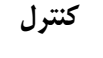 & مداخله & & انحراف معيار土ميانكَين & انحراف معيار土ميانكَين & \\
\hline 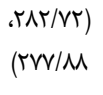 & $\begin{array}{l}r(T N / / V Q) \\
(T Y N / r .\end{array}$ & $P=\cdot / \wedge \Delta \mathcal{F}_{*}$ & $r \Lambda \cdot / r \cdot \pm \varepsilon / \Lambda r$ & $r \Lambda \cdot / \cdot r \pm \psi / q 1$ & سن باردارى در هنًَام زايمان (روز) \\
\hline $\begin{array}{l}\text { ITYT/QD) } \\
(\backslash \Lambda) / 1 \text {. }\end{array}$ & $\begin{array}{l}. T Y N / T V) \\
(1 F \Delta / 99\end{array}$ & $P=\cdot / r \mid \mu_{*}$ & $r \Delta T / \cdot r \pm r \cdot . / \cdot r$ & 19V/Ir & طول مدت يارتى كيسه آب (دقيقه) \\
\hline $\begin{array}{l}(\Delta \Lambda \cdot / r q) \\
(\tau \cdot q / r V\end{array}$ & $\begin{array}{l}\text { ITH/FY }) \\
(T Y T / \Delta V\end{array}$ & $P=\cdot / \cdot||^{f *}$ & TFD/DTIFT/VE & $r \cdot r / q V \pm r V / r q$ & ميزان مايعات دريافتى وريدى در طول مرحله اول ليبر \\
\hline $\begin{array}{l}1+. / 99) \\
(9 T / \pi 4\end{array}$ & $\begin{array}{l}(11 \Delta / \Delta \cdot) \\
(1 \cdot r / 9 q\end{array}$ & $P<\cdot / . \cdot 1 *$ & $Q \varepsilon / 9 \cdot \pm \mid r / r \Lambda$ & $1 \cdot 9 / 9 \cdot \pm|\infty / 1|$ & رضايت از زايمان \\
\hline & & \multirow[t]{2}{*}{ نتيجه آزمون } & (سب نفر ) & (+بانفر) & \multirow[t]{2}{*}{ متغير } \\
\hline & & & (درصد) تعداد & (درصد) تعداد & \\
\hline & & \multirow{2}{*}{$P=\cdot / 11 \cdot * *$} & r & $10(\Delta \cdot / \cdot)$ & \multirow{2}{*}{ تقويت ليبر } \\
\hline & & & $1 \cdot(\mu \cdot / \mu)$ & $10(\Delta \cdot / \cdot)$ & \\
\hline & & \multirow{2}{*}{$P=\cdot / \Gamma \cdot \varphi_{* * *}$} & $\operatorname{lf}(F r / F)$ & $q(\mu \cdot / \cdot)$ & \multirow{2}{*}{ 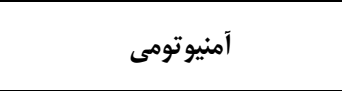 } \\
\hline & & & $19(\Delta \vee / 8)$ & $r I(V \cdot)$ & \\
\hline & & \multirow{2}{*}{$P=\cdot / \cdot \mid$ 人*** } & $r r(99 / v)$ & $I T(F \cdot / \cdot)$ & \multirow{2}{*}{ هيوسين } \\
\hline & & & $1 \cdot(r \cdot / \mu)$ & $11(9 \cdot / \cdot)$ & \\
\hline & & \multirow{2}{*}{$P=\cdot /|\mathrm{V}| * *$} & $\mathbb{1 r}(r q / r)$ & $V(T r / \Gamma)$ & \multirow{2}{*}{ يرومتازين } \\
\hline & & & $r \cdot(\xi \cdot / q)$ & $r \mu(V \& / V)$ & \\
\hline & & \multirow{2}{*}{ 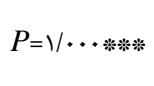 } & $1(\% / \cdot)$ & $\cdot(\cdot / \cdot)$ & \multirow{2}{*}{ خونريزى يس از زايمان } \\
\hline & & & rr (qV/•) & $r \cdot(1 \cdot \cdot)$ & \\
\hline
\end{tabular}

*تى مستقل، ** كاى اسكوئر، **** دقيق فيشر، ***** من ويتنى

جدول f - مقايسه بيامدهاى نوزادى در دو تروه مداخله و كنترل

\begin{tabular}{|c|c|c|c|c|c|c|}
\hline \multicolumn{2}{|c|}{ فاصله اطمينان ه9 } & \multirow{2}{*}{ ن ن نيجه آزمون } & $\begin{array}{c}\text { كنترل } \\
\text { (بس نفر) }\end{array}$ & مداخله & & \multirow{2}{*}{ متغير } \\
\hline كنترل & مداخله & & انحراف معيار ذميانكَين & انحراف معيار_ميانغَين & & \\
\hline \multirow{5}{*}{ 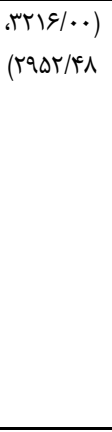 } & $\begin{array}{l}r r \Delta \cdot / \cdot r) \\
(r q \wedge q / r .\end{array}$ & $P=. / 999 *$ & $r \cdot \Lambda F / r F \pm r r / \Delta \Lambda$ & $r 11 q / \varepsilon q \pm \mu r q / l$. & & وزن نوزاد \\
\hline & & $P=\cdot / \Gamma \varphi \cdot$ 䄅䄅 & $\begin{array}{c}\text { I ( } / \cdot \cdot) \\
\operatorname{rr}(q \vee / \cdot)\end{array}$ & $\begin{array}{c}\cdot(\cdot / \cdot) \\
r \cdot(1 \cdot \cdot / \cdot)\end{array}$ & بيشتر از Vمتر از V V & آيًَار دقيقه اول نوزاد \\
\hline & & & $1(\mu / \cdot)$ & $\cdot(\cdot / \cdot)$ & كمتر از V & \\
\hline & & $P=\cdot / \Gamma \digamma \cdot$ 米䄅 & $r r(q \vee / \bullet)$ & $r \cdot(1 . \cdot / \cdot)$ & بيشتر از V & آيخًار دقيقه ينج نوزاد \\
\hline & & $P=\cdot / \Gamma \digamma \cdot * * * *$ & $\begin{array}{l}r(q / 1) \\
r \cdot(q \cdot / q)\end{array}$ & $\begin{array}{c}\cdot(\cdot / \cdot) \\
r \cdot(1 \cdot \cdot)\end{array}$ & 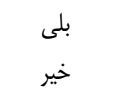 & بسترى در واحد مراقبتهاى ويزه \\
\hline
\end{tabular}


ترس از زايمان را ندارد. از دلايل اين عدم همسو بودن مىتوان به

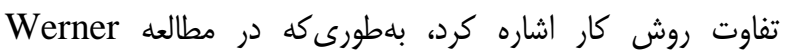

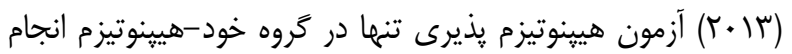

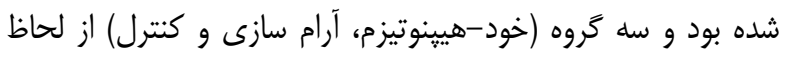
ميزان هيينوتيزم يذيرى همكن نبودند. در مطالعه حاضر از تكنيك

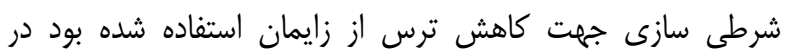
حاليكه در مطالعه Werner و همكاران (rآ+r) نحوه انجام خود-

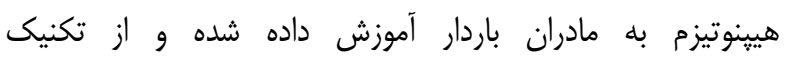

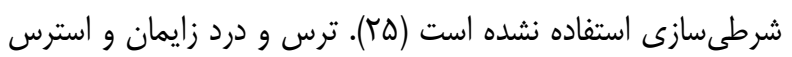
ناشى از آن به حدّى است كه توانايى تمركز براى انجام صحيح

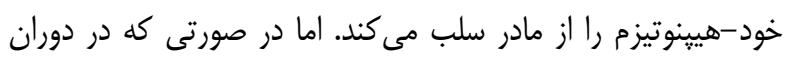

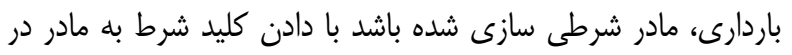

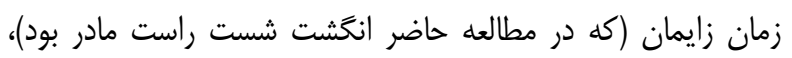

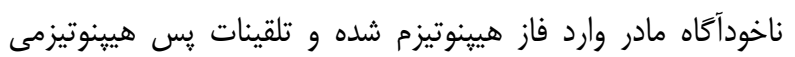
(آرام سازى و شل شدكى عضلانى و انفكاك از انقباضات) كه از قبل هيل

$$
\text { در طى دوران باردارى به او القا كرده ايم اجرا مىشود. }
$$

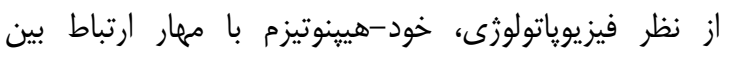

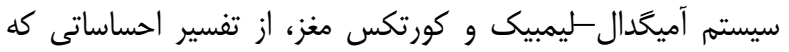

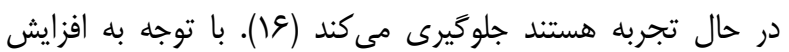

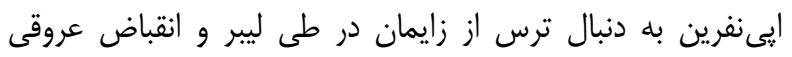

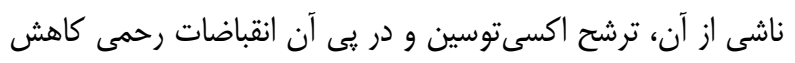

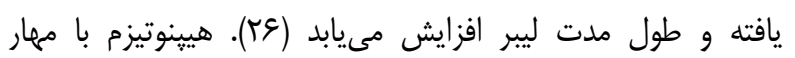

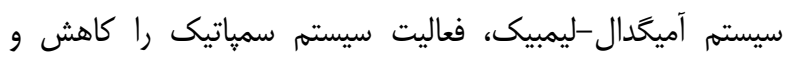

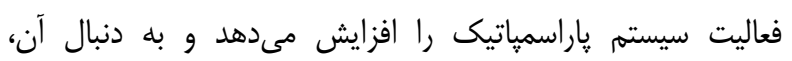
انقباض ماهيجهها و ترس و اضطراب نيز كاهش مىيابد (TV).

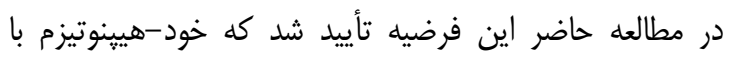
كاهش ترس از زايمان، توانسته است طول مدت مرحله دوم و سوم ليبر را كاهش دهد. اين يافته با نتايج مطالعه Atis و همكاران

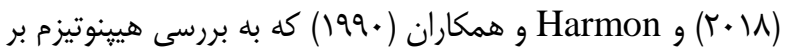
طول مدت ليبر يرداخته بودند همسو، (T/, (T)) و با نتايج مطالعه و همكاران (r) Werner

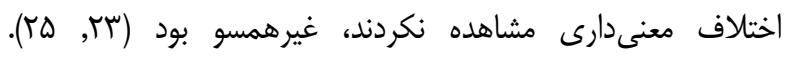

مطالعه حاضر با هدف تأثير خود-هيينوتيزم بر تجربه ترس از

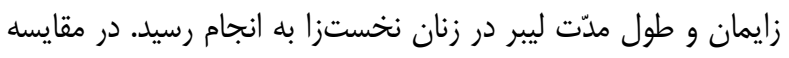

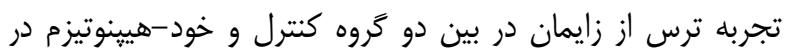

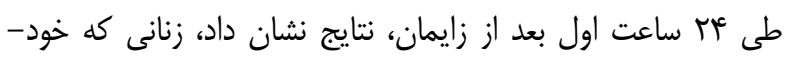

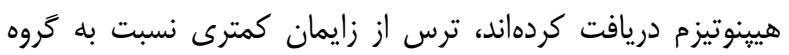
كنترل تجربه كردهاند. همجنين نتايج نشان داد كه طول مدّت مرحله

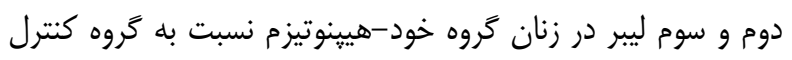

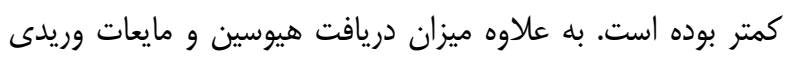
در طى مرحله اول ليبر در زنان دريافت كننده خود-هيينوتيزم نيز

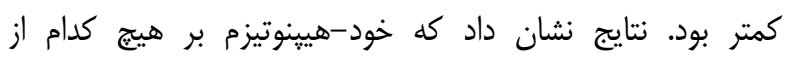
يبامدهاى مادرى و نوزادى تأثير منفى نداشته و روشى ايمن براى داى دادي كاهش ترس از زايمان و طول مدت مرحله دوم و سوم زايمان بوده

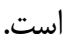
نتايج مطالعه حاضر با سه مطالعه كه تزارش كرده بودند هيينوتيزم يا خود-هيينوتيزم در كاهش تجربه ترس از زايمان مؤثر

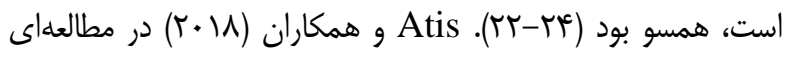

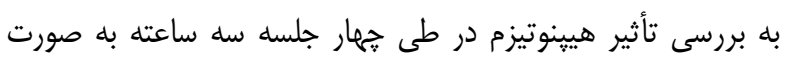
فردى بر ترس و درد زايمان يرداخته بودند و به اين نتيجه رسيدند كه هيينوتيزم در كاهش تجربه ترس از زايمان مؤثر بوده است (T) برد).

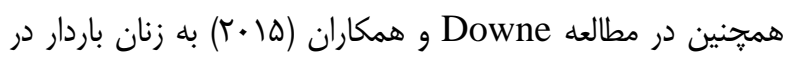

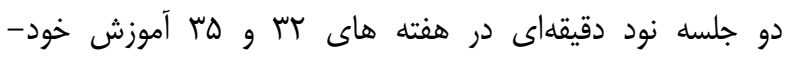
هيينوتيزم داده شد و زنان تا زمان زايمان به شنود فايل صوتى دونى

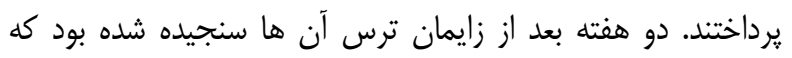
ميزان ترس در كروه مداخله كاهش يافته بود (بآ). در مطالعه

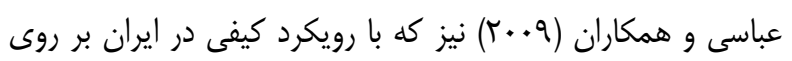

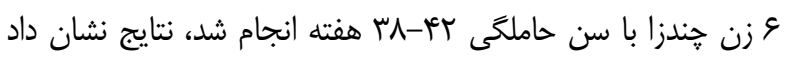

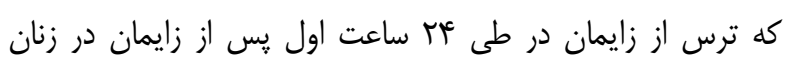

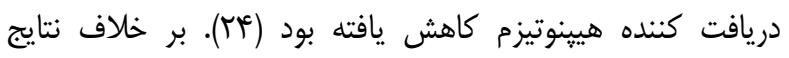

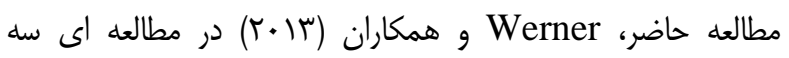

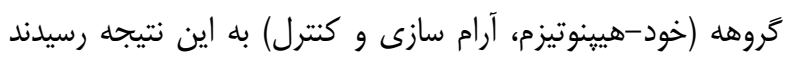

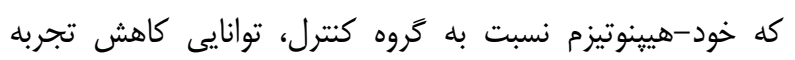


تصادفى وجود داشته است.

\section{نتيجه Fيرى}

در نهايت نتايج اين بزوهش حاكى از آن بود خود-هيينوتيزم در كاهش ترس از زايمان و طول مدّت مرحله دوم و سوم ليبر در زنان نخستزا مؤثر بود. يِيشنهاد مى شود يزوهش هاى بعدى به بررسى تاثير خود-هيينوتيزم در زنان جندزاو مقايسه تأثير خود-هيينوتيزم و هيينوتيزم بر ترس زايمان و طول مدت ليبر انجام شود.

\section{تقدير و تشكر}

اين مقاله حاصل بخشى از طرح تحقيقاتى پايان نامه كارشناسى

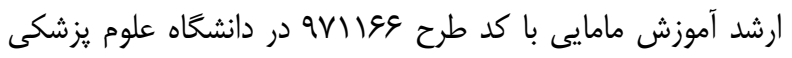
مشهد مىباشد. حمايت مالى اين طرح بر عهده معاونت محترم يزوهشى دانشكاه علوم يزشكى بوده است. در ضمن هيج كدام از

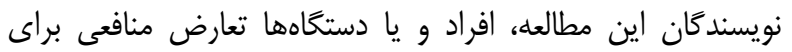
انتشار اين مقاله ندارند. بدين وسيله از اساتيد محترم دانشكده يرستارى مامايى و همكارى صميمانه كاركنان بيمارستان امالبنين(س) و مادران عزيزى كه ما را در انجام اين مطالعه يارى فالهان

$$
\text { نمودند تشكّر و قدردانى مى و مودد. }
$$

\section{تضاد منافع}

نويسندكان مقاله اعلام مىدارند كه هيج كَونه تضاد منافعى در

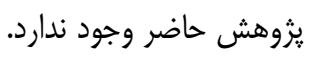

برخلاف تمام مطالعات؛ Freeman و همكاران (ع/91) ذكر كرده است كه زنان برايمى پارى كه خود-هيينوتيزم دريافت كردهاند طول

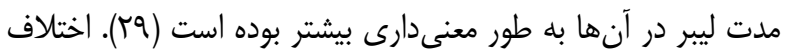

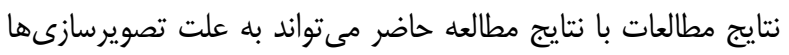
و تلقينهاى متفاوت در هيينوتيزم باشد. به علاوه در مطالعه Harmon

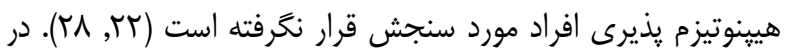

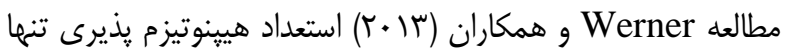

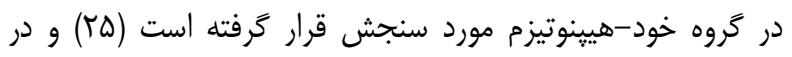
مطالعه Freeman و همكاران (19/1) افراد با استعداد هيينوتيزم

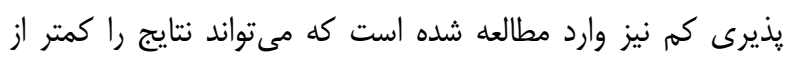
واقعى نشان دهد (rq). از محدوديتهاى اين مطالعه مىتوان به تفاوت نخرشهاى

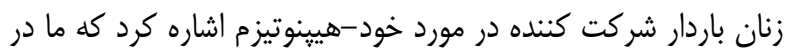

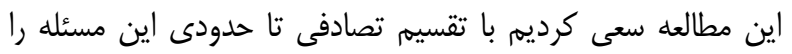

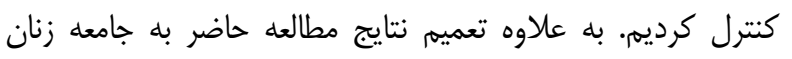
ايرانى نخستزا مشابه با مشخصات دموگرافيك و مامايى مطالعه

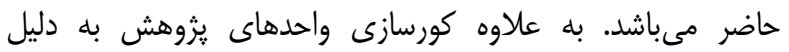

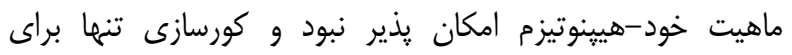
متخصص آمار كه مسئول تجزيه و تحليل دادهها بود انجام شد. از ديخر محدوديتها مى توان به مراقبت ماماهاى مختلف از مادر اشاره

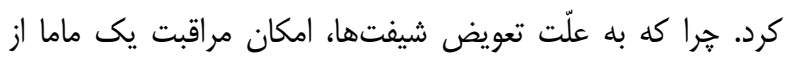

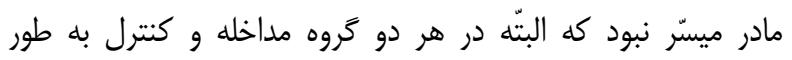

1- Marshall JE, Raynor MD. Myles' Textbook for Midwives E-Book. Translated by: Khaleghi nejad Kh, Shojaian Z, Nekoei T. Tehran: Parastaran Javan; 2011. [Persian].

2- Eriksson C, Jansson L, Hamberg K. Women's experiences of intense fear related to childbirth investigated in a Swedish qualitative study. Midwifery. 2006; 22(3): 240-8. DOI: 10.1016/j.midw.2005.10.002.

3- Wijma K, Wijma B, Zar M. Psychometric aspects of the W-DEQ; a new questionnaire for the measurement of fear of childbirth. J Psychosom Obstet Gynaecol. 1998; 19(2): 84-97. DOI: 10.3109/01674829809048501.

4- Mortazavi F, Agah J. Childbirth fear and associated factors in a sample of pregnant Iranian women. Oman Med J. 2018; 33(6): 497. DOI: 10.5001/omj.2018.91. 
5- Şahin N, Hüsniye D, Dişsiz M. Gebelerin doğuma ilişkin korkuları ve etkileyen faktörler. Zeynep Kamil Tıp Bülteni. 2009; 40(2): 57-62. [Turkish]

6- Gholami A, Salarilak S. Why do some pregnant women prefer cesarean delivery in first pregnancy? Iran J Reprod Med. 2013; 11(4): 301-8.

7- Serçekuş P, Okumuş H. Fears associated with childbirth among nulliparous women in Turkey. Midwifery. 2009; 25(2): 155-62. DOI: 10.1016/j.midw.2007.02.005

8- Kennell J, Klaus M, McGrath S, Robertson S, Hinkley C. Continuous emotional support during labor in a US hospital: a randomized controlled trial. Jama. 1991; 265(17): 2197-201.

9- Floris L, Irion O. Association between anxiety and pain in the latent phase of labour upon admission to the maternity hospital: a prospective, descriptive study. J Health Psychol. 2015; 20(4): 446-55. DOI: $10.1177 / 1359105313502695$.

10- Bonari L, Pinto N, Ahn E, Einarson A, Steiner M, Koren G, et al. Perinatal risks of untreated depression during pregnancy. Can J Psychiatry. 2004; 49(11): 726-35. DOI: 10.1177/070674370404901103.

11- Moghaddam Hosseini V, Nazarzadeh M, Jahanfar S. Interventions for reducing fear of childbirth: A systematic review and meta-analysis of clinical trials. Women Birth. 2018; 31(4): 254-262. DOI: $10.1016 /$ j.wombi.2017.10.007

12- Larsson B, Karlström A, Rubertsson C, Hildingsson I. Counseling for childbirth fear-a national survey. Sex Reprod Healthc. 2016; 8: 82-7. DOI: 10.1016/j.srhc.2016.02.008.

13- Guszkowska M. The effect of exercise and childbirth classes on fear of childbirth and locus of labor pain control. Anxiety Stress Coping. 2014; 27(2): 176-89. DOI: 10.1080/10615806.2013.830107.

14- Elkins GR, Barabasz AF, Council JR, Spiegel D. Advancing research and practice: The revised APA Division 30 definition of hypnosis. Int J Clin Exp Hypn. 2015; 63(1): 1-9. DOI: 10.1080/00207144.2014.961870.

15- Ketterhagen D, VandeVusse L, Berner MA. Self-hypnosis: alternative anesthesia for childbirth. MCN Am J Matern Child Nurs. 2002; 27(6): 335-40. DOI: 10.1097/00005721-200211000-00007.

16- Faymonville ME, Laureys S, Degueldre C, DelFiore G, Luxen A, Franck G, et al. Neural mechanisms of antinociceptive effects of hypnosis. Anesthesiology: Anesthesiology. 2000; 92(5): 1257-67. DOI: 10.1097/00000542-200005000-00013.

17- Beaufort IN, De Weert-Van Oene GH, Buwalda VA, de Leeuw JRJ, Goudriaan AE. The Depression, Anxiety and Stress Scale (DASS-21) as a Screener for Depression in Substance Use Disorder Inpatients: A Pilot Study. Eur Addict Res. 2017; 23(5): 260-8. DOI: 10.1159/000485182.

18- Spiegel H, Spiegel D. Trance and treatment: Clinical uses of hypnosis. Washington, DC; American Psychiatric Pub; 2008.

19- Mortazavi F. Validity and reliability of the Farsi version of Wijma delivery expectancy questionnaire: an exploratory and confirmatory factor analysis. Electron Physician. 2017; 9(6): 4606-15. doi: 10.19082/4606

20- Sahebi A, Asghari MJ, Salari RS. Validation of depression anxiety and stress scale (DASS-21) for an Iranian population. Iranian Psychologists. 2005; 1(4):36-54.

21- Moudi Z, Tavousi M. Evaluation of Mackey childbirth satisfaction rating scale in Iran: what are the psychometric properties? Nurs Midwifery Stud. 2016; 5(2) :e29952. DOI: 10.17795/nmsjournal29952.

22- Atis FY, Rathfisch G. The effect of hypnobirthing training given in the antenatal period on birth pain and fear. Complement Ther Clin Pract. 2018; 33: 77-84. DOI: 10.1016/j.ctcp.2018.08.004.

23- Downe S, Finlayson K, Melvin C, Spiby H, Ali S, Diggle P, et al. Self- hypnosis for intrapartum pain management in pregnant nulliparous women: a randomised controlled trial of clinical effectiveness. BJOG. 2015; 122(9): 122634. DOI: $10.1111 / 1471-0528.13433$. 
24- Abbasi M, Ghazi F, Barlow-Harrison A, Sheikhvatan M, Mohammadyari F. The effect of hypnosis on pain relief during labor and childbirth in Iranian pregnant women. Int J Clin Exp Hypn. 2009; 57(2): 174-83. DOI: $10.1080 / 00207140802665435$.

25- Werner A, Uldbjerg N, Zachariae R, Nohr EA. Effect of self- hypnosis on duration of labor and maternal and neonatal outcomes: a randomized controlled trial. Acta Obstet Gynecol Scand . 2013;92(7): 816-23. DOI: $10.1111 /$ aogs.12141.

26- Zar M, Wijma K, Wijma B. Pre-and postpartum fear of childbirth in nulliparous and parous women. Scand J Behav Ther. 2001; 30(2): 75-84.

27- Berger MM, Davadant M, Marin C, Wasserfallen J-B, Pinget C, Maravic P, et al. Impact of a pain protocol including hypnosis in major burns. Burns. 2010; 36(5): 639-46. DOI: 10.1016/j.burns.2009.08.009

28- Harmon TM, Hynan MT, Tyre TE. Improved obstetric outcomes using hypnotic analgesia and skill mastery combined with childbirth education. J Consult Clin Psychol. 1990; 58(5): 525. DOI: 10.1037//0022-006x.58.5.525.

29- Freeman R, Macaulay A, Eve L, Chamberlain G, Bhat A. Randomised trial of self hypnosis for analgesia in labour. Br Med J (Clin Res Ed). 1986; 292(6521): 657-8. DOI: 10.1136/bmj.292.6521.657 